\title{
LAPORAN KASUS ABORTUS IMINENS JUNI 2015 FAKTOR RESIKO, PATOGENESIS, DAN PENATALAKSANAAN
}

\author{
A.A Gde Kiki Sanjaya Dharma \\ Fakultas Kedokteran Universitas Udayana \\ (anakaqunakiki@yahoo.co.id)
}

\section{ABSTRAK}

Pendahuluan:Salah satu komplikasi terbanyak pada kehamilan adalah terjadinya perdarahan, yang dapat terjadi pada setiap usia kehamilan. Pada kehamilan muda, sering dihubungkan dengan abortus, miscarriage, dan early pregnancy loss. Abortus didefinisikan sebagai suatu ancaman atau pengeluaran hasil konsepsi sebelum janin dapat hidup diluar kandungan. Batasannya adalah usia kehamilan kurang dari 20 minggu atau berat janin kurang dari 500 gram. Abortus iminens adalah perdarahan pervaginam pada kehamilan sebelum 20 minggu tanpa disertai keluarnya hasil konsepsi dan dilatasi uterus.

Kasus:Pasien perempuan, 31 tahun, Suku Bali datang ke UGD rumah sakit dengan keluhan perdarahan pervaginam. Dikatakan perdarahan awalnya berupa flek-flek yang warnanya merah. Kemudian terdapat gumpalan-gumpalan darah berwarna hitam, tidak terdapat jaringan.

Kata Kunci :Abortus iminens, kehamilan, perdarahan.

\section{ABSTRACT}

Introduction: One of the most complications in pregnancy it was a bleeding, that could happen to any the gestational age .Young in pregnancy, often connected with abortus, miscarriage, and loss of early pregnancy .Abortus is defined as the threat or spending the products of conception before a fetus can live outside the utery. Constitutes gestational age is less than 20 weeks or fetus weight less than 500 grams .Abortus imminens is pervaginam bleeding in pregnancy before 20 weeks without accompanied the release of the products of conception and dilatation of the uterus.

Cases: Female patient , 31 years, the balinese ethnic coming to the emergency room the hospital with complaints pervaginam bleeding .Said to be initially were bleeding spots that its color red.Then there are black coloured bloodlump, there is no tissue.

Kata Kunci :Abortus imminens, pregnancy, bleeding.

\section{Pendahuluan}

Salah satu komplikasi terbanyak pada kehamilan adalah terjadinya perdarahan, yang dapat terjadi pada setiap usia kehamilan. Pada kehamilan muda, sering dihubungkan dengan abortus, miscarriage, dan early pregnancy loss. ${ }^{1}$

World Health Organization (WHO) melaporkan terdapat 210 kematian wanita tiap 100.000 kelahiran hidup akibat komplikasi kehamilan dan persalinan pada tahun 2013, dan jumlah total kematian wanita adalah 289.000 kematian. Jumlah ini menurun sebesar $45 \%$ bila dibandingkan tahun 1993 di mana Maternal Mortality Rate (MMR) pada tahun tersebut sebesar 380 dan jumlah kematian wanita 523.000. Negara berkembang memiliki jumlah MMR empat belas kali lipat lebih tinggi dibandingkan negara maju. Berdasarkan survei terakhir tahun 2012 yang dilakukan oleh Survei Demografi dan Kesehatan Indonesia (SKDI), AKI menunjukkan kenaikan dari 228 di tahun 2007 menjadi 359 kematian ibu per 100.000 kelahiran hidup di tahun 2012 . $^{2}$
Abortus didefinisikan sebagai suatu ancaman atau pengeluaran hasil konsepsi sebelum janin dapat hidup diluar kandungan. Batasannya adalah usia kehamilan kurang dari 20 minggu atau berat janin kurang dari 500 gram. Abortus yang berlangsung tanpa tindakan disebut abortus spontan. Abortus provokatus adalah pengakhiran kehamilan sebelum 20 minggu dengan disengaja. Abortus terapeutik ialah abortus provokatus yang dilakukan atas indikasi medik. ${ }^{1}$

Berdasarkan aspek klinisnya, abortus spontan dibagi menjadi beberapa kelompok, yaitu abortus imminens (threatened abortion), abortus insipiens (inevitable abortion), abortus inkomplit, abortus komplit, missed abortion, dan abortus habitualis (recurrent abortion), abortus infeksiosus, dan abortus septik. ${ }^{1,3}$

Abortus iminens adalah perdarahan pervaginam pada kehamilan sebelum 20 minggu tanpa disertai keluarnya hasil konsepsi dan dilatasi uterus.Reproduksi manusia relatif tidak efisien, dan 
abortus adalah komplikasi tersering pada kehamilan, dengan kejadian keseluruhan sekitar $15 \%$ dari kehamilan yang ditemukan. ${ }^{3,4}$ Namun angka kejadian abortus sangat tergantung kapada riwayat obstetri terdahulu, dimana kejadiannya lebih tinggi pada wanita yang sebelumnya mengalami keguguran daripada pada wanita yang hamil dan berakhir dengan kelahiran hidup. ${ }^{4}$

Prevalensi abortus juga meningkat dengan bertambahnya usia, dimana pada wanita berusia 20 tahun adalah $12 \%$, dan pada wanita diatas 45 tahun adalah $50 \% .{ }^{4}$ Delapan puluh persen abortus terjadi pada 12 minggu pertama kehamilan. ${ }^{3}$

Insiden abortus spontan secara umum pernah disebutkan sebesar $10 \%$ dari seluruh kehamilan. Angka tersebut berasal dari data-data dengan sekurangkurangnyaada 2 hal yang selalu berubah, yaitu kegagalan untuk mengikutsertakan abortus diniyang karena itu tidak diketahui, dan pengikutsertaan abortus yang ditimbulkan secarailegal serta dinyatakan sebagai abortus spontan. Abortus iminens sendiri merupakan salah satu bentuk klinis dari abortus spontan maupun sebagai komplikasi dari abortus provokatus kriminalis ataupun medisinalis. Insiden abortus inkompit sendiri belum diketahui secara pasti namun yang penting diketahui adalah sekitar $60 \%$ dari wanita hamil yang mengalami abortus inkomplit memerlukan perawatan rumah sakit akibat perdarahan yang terjadi. ${ }^{1,2,3}$

Abortus iminens dapat berujung pada abortus inkomplet yang memiliki komplikasi yang dapat mengancam keselamatan ibu karena adanya perdarahan masif yang bisa menimbulkan kematian akibat adanya syok hipovolemik apabila keadaan ini tidak mendapatkan penanganan yang cepat dan tepat. Seorang ibu hamil yang mengalami abortus inkomplit dapat mengalami guncangan psikis, tidak hanya pada ibu namun juga pada keluarganya, terutama pada keluarga yang sangat menginginkan anak.

Sangat penting bagi para pelayan kesehatan untuk mengetahui lebih dalam tentang abortus iminensagar mampu menegakkan diagnosis dan kemudian memberikan penatalaksanaan yang sesuai dan akurat, serta mencegah komplikasi.

\section{Etiologi}

Mekanisme pasti yang bertanggungjawab atas peristiwa abortus tidak selalu tampak jelas. Pada beberapa bulan pertama kehamilan, ekspulsi hasil konsepsi yang terjadi secara spontan hampir selalu didahului kematian embrio atau janin, namun pada kehamilan beberapa bulan berikutnya, sering janin sebelum ekspulsi masih hidup dalam uterus.
Kematian janin sering disebabkan oleh abnormalitas pada ovum atau zigot atau oleh penyakit sistemik pada ibu, dan kadang-kadang mungkin juga disebabkan oleh penyakit dari ayahnya ${ }^{1,6}$.

\section{- Perkembangan Zigot yang Abnormal}

Abnormalitas kromosom merupakan penyebab dari abortus spontan. Sebuah penelitian meta-analisis menemukan kasus abnormalitas kromosom sekitar $49 \%$ dari abortus spontan. Trisomi autosomal merupakan anomali yang paling sering ditemukan (52\%), kemudian diikuti oleh poliploidi (21 \%) dan monosomi X $(13 \%)^{1,6}$.

\section{- Faktor Maternal}

Biasanya penyakit maternal berkaitan dengan abortus euploidi. Peristiwa abortus tersebut mencapai puncaknya pada kehamilan 13 minggu, dan karena saat terjadinya abortus lebih belakangan, pada sebagian kasus dapat ditentukan etiologi abortus yang dapat dikoreksi. Sejumlah penyakit, kondisi kejiwaan dan kelainan perkembangan pernah terlibat dalam peristiwa abortus euploidi ${ }^{1,6}$.

\section{a.Infeksi}

Organisme seperti Treponema pallidum, Chlamydia trachomatis, Neisseria gonorhoeae, Streptococcus agalactina, virus herpes simplek, cytomegalovirus Listeria monocytogenes dicurigai berperan sebagai penyebab abortus. Toxoplasma juga disebutkan dapat menyebabkan abortus. Isolasi Mycoplasma hominis dan Ureaplasma urealyticum dari traktus genetalia sebagaian wanita yang mengalami abortus telah menghasilkan hipotesis yang menyatakan bahwa infeksi mikoplasma yang menyangkut traktus genetalia dapat menyebabkan abortus. Dari kedua organisme tersebut, Ureaplasma Urealyticum merupakan penyebab utama ${ }^{1}$.

\section{b. Penyakit-Penyakit Kronis yang Melemahkan}

Pada awal kehamilan, penyakit-penyakit kronis yang melemahkan keadaan ibu misalnya penyakit tuberkulosis atau karsinomatosis jarang menyebabkan abortus $^{1,6}$.

Hipertensi jarang disertai dengan abortus pada kehamilan sebelum 20 minggu, tetapi keadaan ini dapat menyebabkan kematian janin dan persalinan prematur. Diabetes maternal pernah ditemukan oleh sebagian peneliti sebagai faktor predisposisi abortus spontan, tetapi kejadian ini tidak ditemukan oleh peneliti lainnya ${ }^{1}$.

\section{c. Pengaruh Endokrin}

Kenaikan insiden abortus bisa disebabkan oleh hipertiroidisme, diabetes mellitus, dan defisiensi progesteron. Diabetes tidak menyebabkan abortus jika kadar gula dapat dikendalikan dengan baik. Defisiensi progesteron karena kurangnya sekresi hormon tersebut dari korpus luteum atau plasenta mempunyai hubungan dengan kenaikan insiden abortus. Karena progesteron 
berfungsi mempertahankan desidua, defisiensi hormon tersebut secara teoritis akan mengganggu nutrisi pada hasil konsepsi dan dengan demikian turut berperan dalam peristiwa kematiannya ${ }^{1,5,6}$.

\section{d. Nutrisi}

Pada saat ini, hanya malnutrisi umum sangat berat yang paling besar kemungkinanya menjadi predisposisi meningkatnya kemungkinan abortus. Nausea serta vomitus yang lebih sering ditemukan selama awal kehamilan dan setiap deplesi nutrient yang ditimbulkan, jarang diikuti dengan abortus spontan. Sebagaian besar mikronutrien pernah dilaporkan sebagai unsur yang penting untuk mengurangi abortus spontan ${ }^{1,5,6}$.

\section{e. Obat-Obatan dan Toksin Lingkungan}

Berbagai macam zat dilaporkan berhubungan dengan kenaikan insiden abortus. Namun ternyata tidak semua laporan ini mudah dikonfirmasikan.

\section{f. Faktor-faktor Imunologis}

Faktor imunologis yang telah terbukti signifikan dapat menyebabkan abortus spontan yang berulang antara lain : lupus anticoagulant (LAC) dan anticardiolipin antibody (ACA) yang mengakibatkan destruksi vaskuler, trombosis, abortus serta destruksi plasenta.

\section{g. Gamet yang Menua}

Baik umur sperma maupun ovum dapat mempengaruhi angka insiden abortus spontan. Insiden abortus meningkat terhadap kehamilan yang berhasil bila inseminasi terjadi empat hari sebelum atau tiga hari sesudah peralihan temperatur basal tubuh, karenaitu disimpulkan bahwa gamet yang bertambah tua di dalam traktus genitalis wanita sebelum fertilisasi dapat menaikkan kemungkinan terjadinya abortus. Beberapa percobaan binatang juga selaras dengan hasil observasi tersebut ${ }^{1,6}$.

\section{h. Laparotomi}

Trauma akibat laparotomi kadang-kadang dapat mencetuskan terjadinya abortus. Pada umumnya, semakin dekat tempat pembedahan tersebut dengan organ panggul, semakin besar kemungkinan terjadinya abortus. Meskipun demikian, sering kali kista ovarii dan mioma bertangkai dapat diangkat pada waktu kehamilan apabila mengganggu gestasi. Peritonitis dapat menambah besar kemungkinan abortus. ${ }^{1,6}$

\section{i. Trauma Fisik dan Trauma Emosional}

Kebanyakan abortus spontan terjadi beberapa saat setelah kematian embrio atau kematian janin. Jika abortus disebabkan khususnya oleh trauma, kemungkinan kecelakaan tersebut bukan peristiwa yang baru terjadi tetapi lebih merupakan kejadian yang terjadi beberapa minggu sebelum abortus. Abortus yang disebabkan oleh trauma emosional bersifat spekulatif, tidak ada dasar yang mendukung konsep abortus dipengaruhi oleh rasa ketakutan marah ataupun cemas. $^{1,6}$

\section{j. Kelainan Uterus}

Kelainan uterus dapat dibagi menjadi kelainan akuisita dan kelainan yang timbul dalam proses perkembangan janin,defek duktus mulleri yang dapat terjadi secara spontan atau yang ditimbulkan oleh pemberian dietilstilbestrol (DES) ${ }^{5,6}$. Cacat uterus akuisita yang berkaitan dengan abortus adalah leiomioma dan perlekatan intrauteri. Leiomioma uterus yang besar dan majemuk sekalipun tidak selalu disertai dengan abortus, bahkan lokasi leiomioma tampaknya lebih penting daripada ukurannya.

Mioma submokosa, tapi bukan mioma intramural atau subserosa, lebih besar kemungkinannya untuk menyebabkan abortus. Namun demikian, leiomioma dapat dianggap sebagai faktor kausatif hanya bila hasil pemeriksaan klinis lainnya ternyata negatif dan histerogram menunjukkan adanya defek pengisian dalam kavum endometrium. Miomektomi sering mengakibatkan jaringan parut uterus yang dapat mengalami ruptur pada kehamilan berikutnya, sebelum atau selama persalinan.

Perlekatan intrauteri (sinekia atau sindrom Ashennan) paling sering terjadi akibat tindakan kuretase pada abortus yang terinfeksi atau pada missed abortus atau mungkin pula akibat komplikasi postpartum. Keadaan tersebut disebabkan oleh destruksi endometrium yang sangat luas. Selanjutnya keadaan ini mengakibatkan amenore dan abortus habitualis yang diyakini terjadi akibat endometrium yang kurang memadai untuk mendukung implatansi hasil pembuahan.

\section{k. Inkompetensi serviks}

Kejadian abortus pada uterus dengan serviks yang inkompeten biasanya terjadi pada trimester kedua. Ekspulsi jaringan konsepsi terjadi setelah membran plasenta mengalami ruptur pada prolaps yang disertai dengan balloning membran plasenta ke dalam vagina. ${ }^{1,5,6}$

\section{- Faktor Paternal}

Hanya sedikit yang diketahui tentang peranan faktor paternal dalam proses timbulnya abortus spontan. Yang pasti, translokasi kromosom sperma dapat menimbulkan zigot yang mengandung bahan kromosom terlalu sedikit atau terlalu banyak, sehingga terjadi abortus ${ }^{6}$.

\section{a. Faktor fetal}

Kelainan pertumbuhan hasil konsepsi dapat menyebabkan kematian janin atau cacat. Kelainan berat biasanya menyebabkan kematian janin pada hamil muda. Faktor-faktor yang menyebabkan kelainan dalam pertumbuhan janin antara lain kelainan kromosom, lingkungan kurang sempurna dan pengaruh dari luar. Kelainan kromosom merupakan kelainan yang sering 
ditemukan pada abortus spotan seperti trisomi, poliploidi dan kemungkinan pula kelainan kromosom seks. Lingkungan yang kurang sempurna terjadi bila lingkungan endometrium di sekitar tempat implantasi kurang sempurna sehingga pemberian zat-zat makanan pada hasil konsepsi terganggu. Pengaruh dari luar seperti radiasi,virus, obat-obat yang sifatnya teratogenik. ${ }^{1,5,6}$

\section{b. Faktor plasenta}

Seperti endarteritis dapat terjadi dalam villi koriales dan menyebabkan oksigenasi plasenta terganggu, sehingga menyebabkan gangguan pertumbuhan dan kematian janin. Keadaan ini bisa terjadi sejak kehamilan muda misalnya karena hipertensi yang menahun.

\section{Patogenesis}

Proses abortus iminensbiasanya berlangsung secara spontan maupun sebagai komplikasi dari abortus provokatus kriminalis ataupun medisinalis. Proses terjadinya berawal dari pendarahan pada desidua basalis yang menyebabkan nekrosis jaringan diatasnya. Pada abortus iminens nekrosis yang terjadi tidak cukup dalam untuk menimbulkan pelepasan hasil konsepsi dari dinding uterus.Namun jika tidak segera ditangani, nekrosis dapat meluas dan menimbulkan inkompetensi desidua dalam menjaga hasil konseptus sehingga dapat berlanjut kepada abortus inkomplet atau komplet. Pada kehamilan antara 8 minggu sampai 14 minggu villi koriales menembus desidua lebih dalam sehingga umumnya plasenta tidak dilepaskan sempurna yang dapat menyebabkan banyak perdarahan. Pada kehamilan lebih dari 14 minggu umumnya yang mulamula dikeluarkan setelah ketuban pecah adalah janin, disusul kemudian oleh plasenta yang telah lengkap terbentuk. Perdarahan tidak banyak jika plasenta segera terlepas dengan lengkap ${ }^{1,6}$.

\section{Diagnosis}

Diagnosis abortus iminens ditentukan karena pada wanita hamil terjadi pendarahan melalui ostium uteri eksternum, disertai mules sedikit atau tidak sama sekali, uterus membesar sebesar usia kehamilan, servik belum membuka, dan tes kehamilan positif, yang biasanya terjadi paruh pertama dari kehamilan. Sering terjadi pendarahan ringan atau yang lebih berat pada awal gestasi yang menetap sampai berhari-hari atau berminggu-minggu. Dari semua itu setengah dari kehamilan ini akan mengalami abortus, walaupun resiko lebih rendah jika denyut jantung janin dapat direkam. Meskipun tanpa terjadinya abortus fetus ini akan mengalami resiko tinggi untuk terjadinya persalinan preterm, bayi lahir rendah, kematian perinatal.
Pentingnya resiko terjadinya malformasi tampak tidak meningkat. ${ }^{1,2,5}$

\section{Kasus}

Pasien perempuan, 31 tahun, beragama Hindu, Suku Bali datang ke UGD rumah sakit pada tanggal 10 Juni 2015 dengan keluhan perdarahan pervaginam sejak pukul 14.00 WITA satu hari yang lalu. Dikatakan perdarahan awalnya berupa flek-flek yang warnanya merah. Kemudian terdapat gumpalan-gumpalan darah berwarna hitam, tidak terdapat jaringan. Keluhan disertai nyeri pada perut bagian bawah. Pasien sebelumnya sempat mengikuti rafting dan berjalan menaiki tangga cukup jauh sehari sebelum keluhan muncul. Riwayat koitus (+) 2 hari sebelum masuk rumah sakit. Riwayat pingsan disangkal.Menarche umur 12 tahun, dengan siklus teratur setiap 28 hari, lamanya 4-5 hari tiap kali menstruasi.Hari pertama haid terakhir 4/4/2015. Pasien menikah satu kali dengan suami yang sekarang selama \pm 1 tahun. Pasien memiliki riwayat abortus komplit pada satu tahun yang lalu saat umur kehamilan 9 minggu sebelum kehamilan pasien saat ini

Pasien pernah USG di dokter spesialis sebanyak 1 kali.Sejak menikah hingga saat ini pasien belum pernah menggunakan alat kontrasepsi. Riwayat penyakit diabetes melitus, asma, hipertensi dan penyakit jantung disangkal oleh pasien dan keluarga pasien.Pasien tidak dalam pengobatan tertentu dan tidak menggunakan obat-obatan terlarang. Hasil normal pada pemeriksaan tanda vital dan pemeriksaan fisik general.

Dari pemeriksaan ginekologi, tidak ada distensi, tidak ada nyeri suprapubik, tidak ada tanda cairan bebas, TFU belum teraba, tidak ada nyeri tekan. Pada vagina ditemukan flek darah dan tidak tampak jaringan. Dari vaginal touché (VT) ditemukan flek darah, tidak ada pembukaan serviks, porsio mencucu, tidak ada jaringan, tidak ada stolsel, tidak ada perdarahan aktif, corpus uteri antefleksi, cavum douglas dalam batas normal.

Dari hasil pemeriksaan USG, blast isi cukup, uterus antefleksi dengan GS intrauterine UK 9 minggu 5 hari, , DJJ 150x/menit, gerak fetus normal, ketuban cukup, tidak tampak cairan bebas, tidak nampak massa di adnexa.

Pasien ditata laksana dengan perawatan inap, infus RL $20 \mathrm{tpm}$, Isoxsuprine $3 \times 10 \mathrm{mg}$ peroral, Allylesterenol $3 \times 10 \mathrm{mg}$ peroral, Asam mefenamat $3 \times$ $500 \mathrm{mg}$ peroral. KIEpasien dan keluarga tentang kondisi janin dan ibu; serta tujuan terapi dan komplikasi. Prognosis pasienDubius ad bonam. 

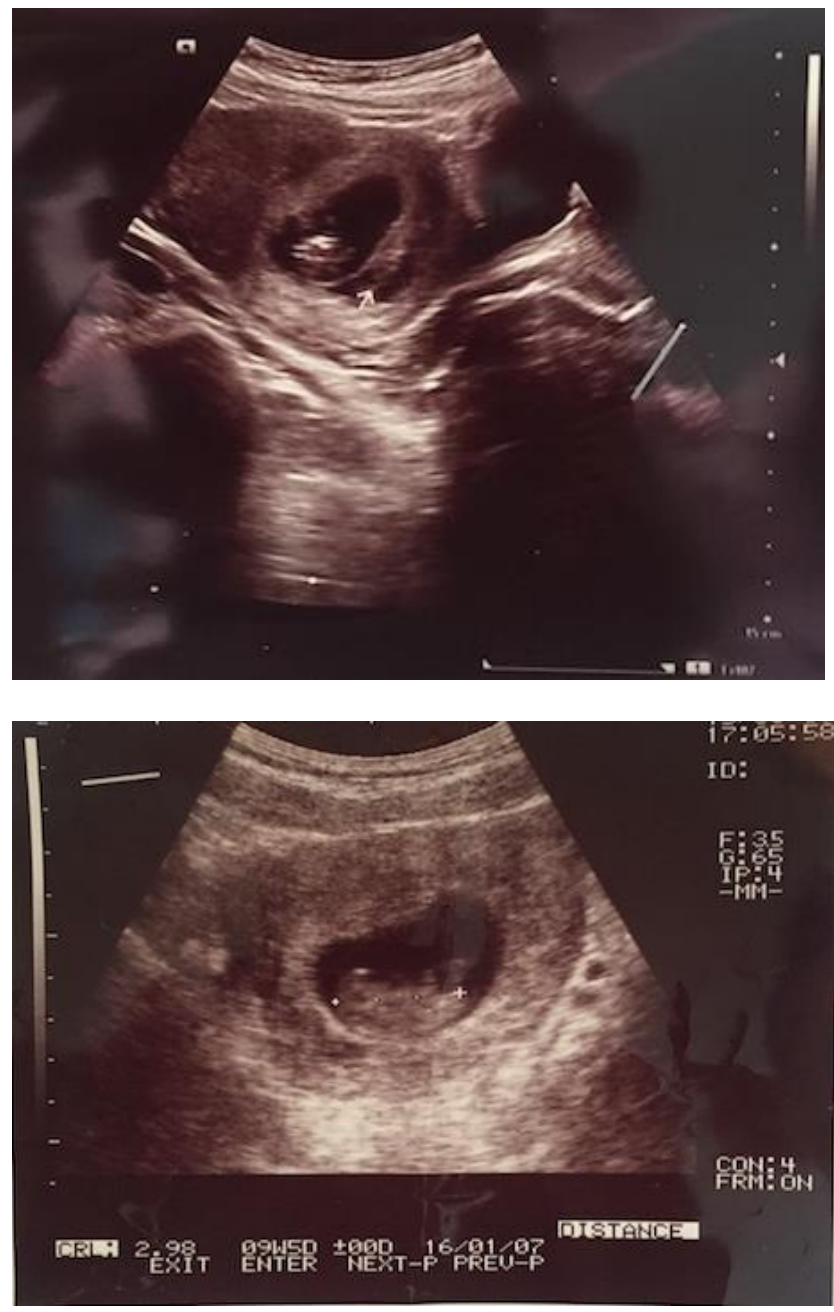

\section{Pembahasan}

\section{- Diagnosis}

Seorang pasien 31 tahun, beragama Hindu, Suku Bali, datang ke UGD rumah sakit pada 10 Juni 2015 dengan keluhan perdarahan pervaginam sejak pukul 14.00 WITA pada satu hari sebelumnya Dikatakan perdarahan awalnya berupa flek-flek yang warnanya merah. Kemudian terdapat gumpalan-gumpalan darah berwarna hitam, tidak terdapat jaringan. Keluhan disertai nyeri pada perut bagian bawah yang ringan. Pasien sebelumnya sempat mengikuti rafting dan berjalan menaiki tangga cukup jauh sehari sebelum keluhan muncul. Riwayat koitus (+) 2 hari sebelum masuk rumah sakit. Riwayat pingsan disangkal.

Pada pemeriksaan fisik didapatkan status present dan general normal, pemeriksaan abdomen fundus uteri tidak teraba, nyeri tekan tidak ada, tanda cairan bebas tidak ada, massa tidak ada. Dari pemeriksaan dalam didapatkan, terdapat fluksus, tidak ada pembukaan OUE, tak tampak jaringan, nyeri goyang porsio negatif.
Pada pasien tersebut, pada anamnesis jelas didapatkan adanya keluhan telat haid yang mendukung bahwa pasien sedang hamil. Selain adanya keluhan perdarahan pervaginam yang banyak tidak didapatkan juga keluhan nyeri perut bagian bawah. Berdasarkan data anamnesis tersebut, maka dapat dipikirkan adanya kecurigaan terhadap gejala abortus, terlebih lagi pasien sedang dalam masa reproduksi. Pada kasus ini, setelah dilakukan pemeriksaan dalam tidak didapatkan adanya pembukaan OUE dan tak terlihat massa/jaringan besar dan konsistensi uterus sesuai dengan usia kehamilan 9 minggu. Tidak ditemukan juga adanya nyeri goyang porsio.

Berdasarkan gambaran klinis yang jelas inilah kemudian dapat ditegakkan diagnosanya menjadi abortus iminens.

Walaupun demikian jika hanya dari anamnesa saja mungkin cukup sulit untuk dapat yakin bahwa itu merupakan suatu abortus iminensoleh karena adanya keluhan perdarahan pervaginam pada kehamilan muda, selain abortus iminensperlu juga dipikirkan kemungkinan lain seperti: kehamilan ektopik, mola hidatidosa.

Pada kehamilan ektopik nyeri perut bawah merupakan keluhan utamanya yang hebat biasanya adalah gejala utamanya, disertai juga keluhan pendarahn pervaginam, serta amenorea. Yang membedakannya dengan abortus yaitu gejala klinis pendarahan yang tidak sesuai dengan jumlah pendarahan. Pasien akan menunjukkan tanda-tanda klinis hipovolemia seperti pucat, hipotensi akibat pendarahan didalam yang hebat. Dari pemeriksaan fisik akan ditemukan nyeri tekan abdomen, sedangkan pada vaginal touche juga akan ditemukan nyeri goyang porsio dan tanda penonjolan kavum douglas disertai nyeri akibat adanya bekuan darah di ruang abdomen.

Kemungkinan lain yang kita perlu pikirkan yaitu diagnosis mola hidatidosa. Yang dimaksud dengan mola hidatidosa adalah kehamilan yang berkembang tidak wajar, dimana terjadi proliferasi trofoblas yang abnormal pada kehamilan,dengan tidak ditemukannya janin dan hampir seluruh vili korealis mengalami perubahan hidrotik. Pada mola perdarahan merupakan gejala utama, dimana sifat perdarahannya bisa intermitten, sedikit-sedikit atau sekaligus banyak yang dapat menyebabkan syok. Pada kasus dengan perdarahan yang banyak sering disertai dengan pengeluaran gelembung dari jaringan mola yang seperti buah anggur. Pada pemeriksaan fisik, besar uterus tidak sesuai dengan usia kehamilan (50\% kasus menunjukkan besar uterus lebih dari usia kehamilan sesungguhnya), tidak ditemukan balotement dan denyut jantung janin. Selain itu pada permulaan kehamilan biasanya pasien 
mengalami hiperemesis gravidarum, mual, muntah pusing dengan derajat keluhan yang lebih berat. Perkembangan kehamilan adalah lebih pesat sehingga pada umumnya didapatkan uterus lebih besar dari umur kehamilan.

Pemeriksaan penunjang yang dapat dilakukan antara lain adalah pemeriksaan laboratorium berupa darah lengkap dan tes kehamilan, dan USG. Pada pemeriksaan darah lengkap, dapat ditemukan hemoglobin $(\mathrm{Hb})$ yang rendah akibat dari perdarahan yang bermakna. Hitung sel darah putih dan laju endap darah meningkat bahkan tanpa adanya infeksi. Menurunnya atau kadar plasma yang rendah dari $\beta-\mathrm{hCG}$ adalah penanda kehamilan abnormal, baik blighted ovum, abotus spontan, ataupun kehamilan ektopik. ${ }^{2}$

Pemeriksaan USG transvaginal berguna untuk mendokumentasikan kehamilan intrauterin. Pada abortus iminens, sakus gestasional biasanya terlihat normal, material ekogenik yang mewakili jaringan plasenta terlihat dalam kavum uteri. $^{2}$

Berdasarkan uraian diatas maka diagnosa pasien cenderung mengarah ke abortus iminens, karena dari anamnesis dan pemeriksaan fisik ginekologi jelas didapatkan gejala klinis yang sesuai dengan abortus iminens. Adanya diagnosa banding yaitu kehamilan ektopik, dan mola dapat disingkirkan. Pemeriksaan penunjang yang dapat dilakukan adalah pemeriksaan hematologi rutin yaitu untuk mencari terutama kadar hemoglobin yang bertujuan dengan mengetahui adanya kadar hemoglobin dibawah normal berarti pasien dalam keadaan anemia yang salah satunya dapat disebabkan oleh adanya perdarahan banyak. Pada kasus ini hasil dari laboratorium darah rutin didapatkan dalam batas normal, sehingga tidak perlu ditakutkan adanya keadaan anemi. Pemeriksaan penunjang lainnya, USG dapat pula menyingkirkan adanya kehamilan ektopik atau suatu mola hidatidosa. Dengan pemeriksaan USG pada trimester awal kehamilan, dapat diketahui kehamilan tersebut intra atau ekstra uteri. Sedangkan pada kasus mola, dengan pemeriksaan USG, menunjukkan gambaran yang khas yaitu berupa badai salju (snow flake pattern). Pada kasus ini dari pemeriksaan USG ditemukan keadaan janin yang masih baik.

\section{- Faktor predisposisi atau etiologi}

Mekanisme pasti yang bertanggungjawab atas peristiwa abortus tidak selalu tampak jelas. Kematian janin sering disebabkan oleh abnormalitas pada ovum atau zigot atau oleh penyakit sistemik pada ibu, dan kadang-kadang mungkin juga disebabkan oleh faktor paternal seperti translokasi kromosom.

Penyebab terjadinya abortus iminenspada pasien ini yang dapat terlihat yaitu adanya riwayat abortus sebelumnya. Penyebab lain yang dapat dipertimbangkan adalah faktor maternal seperti faktor nutrisi, penyakit sistemik atau kelainan anatomi, faktor trauma, paparan obat-obatan dan toksin lingkungan ataupun faktor lain seperti riwayat koitus pada kehamilan usia muda.

Pada kasus abortus iminens ini mungkin dapat lebih diperdalam lagi sehingga dapat diketahui etiologinya (eksplorasi kausa). Faktor yang dapat ditelusuri yaitu ada tidaknya kelainan pada plasenta (end arteritis vili korealis yang dapat dipicu oleh karena hipertensi menahun) serta adanya penyakit pada ibu antara lain pneumoni, tifus abdominalis, malaria, infeksi $\mathrm{TORCH}$, anemia berat, adanya riwayat penggunaan obatobat tertentu yang bersifat teratogenik dan adanya trauma fisik, yang dapat menyebabkan abortus.

Disamping itu juga perlu dipikirkan kemungkinan adanya gangguan pada uterus berupa kelainan hormonal yang mempengaruhi endometrium, kelainan oleh karena factor mekanik (adanya mioma submukus) serta kelainan anatomis (serviks inkompeten, uterus bikornu, uterus arkuatus, dan lain-lain).

Adanya penyakit infeksi akut (pneumonia, malaria) atau penyakit kronis (diabetes mellitus, hipertensi kronis, penyakit liver/ginjal kronis) dapat diketahui lebih mendalam melalui anamnesa yang baik dan terperinci. Penting juga diketahui bagaimana perjalanan penyakitnya jika memang pernah menderita infeksi berat, seperti apakah telah diterapi dengan tepat dan adekuat. Hal ini penting sebagai data dasar untuk nantinya dapat membantu dalam menghubungkan dengan kejadian ROB. Ketidakjelasan secara klinis adanya diabetes melitus atau gangguan kronis pada hepar atau ginjal dapat dibantu dengan pemeriksaan gula darah acak/2 jam pp, liver function test/LFT (AST/ALT) maupun renal function test/RFT (BUN/SC). Untuk eksplorasi kausa, pemeriksaan-pemeriksaan diatas dapat dikerjakan.

Jika ingin mengetahui pengaruh faktor lingkungan, maka perlu ditanyakan tentang lingkungan tempat tinggal ibu, mungkin ada tidaknya riwayat menjalankan radioterapi, maupun lingkungan kerjanya. Ada tidaknya binatang seperti kucing yang dianggap sebagai vektor penularan TORCH, penting juga diketahui. Oleh karena itu boleh disarankan pemeriksaan serologis TORCH untuk mengetahui titer antibodi terhadap virus ini.

Demikian juga penggunaan obat-obatan tertentu yang dianggap teratogenik harus dicari dari anamnesa karena jika ada mungkin hal ini merupakan salah satu faktor yang berperan.

Penyebab lain yang dapat dipertimbangkan sebagai penyebab abortus yaitu riwayat koitus. Seperti diketahui koitus pada usia kehamilan muda memiliki 
resiko tinggi pengeluaran janin sebelum waktunya terkait dengan dilatasi serviks maupun efek prostaglandin dari semen. Begitu juga dengan penyebab lain seperti trauma ataupun aktivitas yang berat yang dapat menyebabkan pengeluaran janin dari tempat perlengkatannya.

Adanya kelainan anatomis pada uterus misalnya serviks inkompeten (mudah berdilatasi) atau kelainan bentuk uterus (bikornus) dapat diketahui dari pemeriksaan USG, histerosalpingografi (HSG), histeroskopi, dan laparoskopi (prosedur diagnostik).

Uraian diatas penting disampaikan kepada pasien agar ia dapat memahami apa kira-kira yang melatarbelakangi penyakitnya.

\section{- Penatalaksanaan}

Pada kasus ini pada saat pasien datang ke rumah sakit keadaan umumnya stabil, dan tidak didapatkan tanda-tanda syok. Oleh karena pada pemeriksaan fisik tidak teraba massa jaringan dan perdarahan berhetnti setelah dilakukan observasi selanjutnya diberikan medikamentosa berupa tokolitik dan vitamin. Sangat penting selama kehamilan untuk monitoring vital sign dan adanya keluhan. Maka dari itu adanya komplikasi seperti perdarahan ringan sampai berat, infeksi, dan kelainan fungsi pembekuan darah dapat dihindari.

Keadaan pasien stabil dan diberikan pengobatan Isoxsuprine dan allylesterenol untuk mempertahankan kondisi uterus yang mana berperan dalam menjaga kandungan dan asam mefenamat untuk analgetik.

KIE merupakan hal yang sangat penting didalam kasus ini dimana yang harus dititik beratkan adalah tentang diagnosis penyakitnya, tindakan apa yang dilakukan terhadap penyakitnya tersebut, komplikasi apa yang dapat terjadi, rencana monitoring kehamilan yang (persiapan untuk faktor anatomi dan psikologis ibu), kontrol atau evaluasi terhadap tindakan (febris, nyeri) dan yang tidak kalah pentingnya adalah mencari penyebab abortus (untuk persiapan kehamilan beikutnya), disamping itu juga terhadap faktor sosial dimana harapan masih bisa hamil lagi, prognosis abortus yang berulang atau tidak.

\section{- Prognosis}

Prognosis pada kasus ini adalah mengarah ke baik, dubius ad bonam karena dengan pemeriksaan penunjang didapatkan kondisi janin yang baik dan setelah observasi tidak didapatkan keluhan dan keadaan umum pasien stabil. Selain itu pada pasien ini tidak didapatkan adanya penyulit atau komplikasi yang berbahaya misalnya perdarahan, perforasi, infeksi dan syok.
Demikian kasus ini kami buat, kritik dan saran yang membangun sangat kami harapkan.

\section{Daftar Pustaka}

1. Wibowo B. Wiknjosastro GH. Kelainan dalam Lamanya Kehamilan. Wiknjosastro GH, Saifuddin $A B$, Rachimhadhi T, editor. Ilmu Kebidanan. Edisi 5. Jakarta : Yayasan Bina Pustaka Sarwono Prawirohardjo ; 2002 : hal. 302 - 312.

2. Pedoman Diagnosis - Terapi Dan Bagian Alir Pelayanan Pasien, Lab/SMF Obstetri dan Ginekologi Fakultas Kedokteran Universitas Udayana RS Sanglah Denpasar. 2003

3. Cunningham FG, dkk. Kehamilan pada Manusia. Dalam Hartanto Huriawati, editor. Obstetric Williams volume satu. Edisi ke-21. Jakarta: ECG. 2006. Hal 2-33

4. Griebel CP, Vorsen JH, Golemon TB, Day AA. Management of Spontaneus Abortion. American Family Physician. October 01 2005;72;1. Accesed on 13 June 2015.

5. Stovall TG. Early Pregnancy Loss and Ectopic Pregnancy. In : Berek JS, et all. Novak's Gynaecology. $13^{\text {th }}$ ed. Philadelphia; 2002 : p. 507 9.

6. Abortion. In : Cunningham FG, Leveno KJ, Bloom SL, Hauth JC, Bilstrap LC, Wenstrom KD, editors. William Obsetrics. 22 ${ }^{\text {nd }}$ ed. USA : The McGrawHills Companies, Inc ; 2005 : p. 231-247.

7. Prosedur Tetap Pelayanan Medis Bagian/SMF Obstetri dan Ginekologi FK UNUD RSUP Sanglah tahun 2004. 